\title{
ERRATUM TO: SYNTHESIS, CHARACTERIZATION, AND COMPUTATIONAL STUDIES \\ OF TRIAZATETRACYCLO ACETAMIDE
}

\author{
F. Odame, E. C. Hosten, and Z. R. Tshentu \\ Journal of Structural Chemistry, Vol. 59, No. 8, pp. 1804-1809, December, 2018. \\ DOI: $10.1134 / \mathrm{S} 0022476619010256$ \\ In the original publication there was a typo in the title of the article. The correct title of the article is \\ SYNTHESIS, CHARACTERIZATION, AND COMPUTATIONAL STUDIES OF TRIAZATETRACYCLO \\ ACETAMIDE.
}

The original article can be found online at https://doi.org/10.1134/S0022476618080073.

Department of Chemistry, Nelson Mandela Metropolitan University, Port Elizabeth, South Africa; felixessah15@gmail.com. 